\title{
PENGARUH SENYAWA SILAN TERHADAP \\ SIFAT MEKANIK MATERIAL PELAPIS PADUAN HIBRID EPOKSI TERMODIFIKASI POLIURETAN
}

\section{THE INFLUENCE OF SILANE ON MECHANICAL PROPERTIES OF MODIFIED EPOXY POLYURETHANE}

\author{
Savitri $^{1)}$, Evi Triwulandari ${ }^{1)}$, Agus Haryono ${ }^{1)}$, O.A. Syahputra ${ }^{2)}$ \\ ${ }^{1)}$ Pusat Penelitian Kimia - LIPI Kawasan Puspiptek Serpong, Tangerang, Indonesia 15314 \\ ${ }^{2)}$ Universitas Negeri Sebelas Maret, FMIPA, Jurusan Kimia, Jl. Ir. Sutami No. 36A, Surakarta, \\ Jawa Tengah 57126 \\ Email : savi002@lipi.go.id
}

Diterima: 03 Maret 2015, Revisi: 13 Maret 2015, Disetujui: 10 April 2015

\begin{abstract}
ABSTRAK
Pembuatan material pelapis hibrid epoksi termodifikasi poliuretan (ETP) dari epoksi, poliuretan dan senyawa silan $(\mathrm{Si})$ telah dilakukan. Resin epoksi dan poliuretan dimodifikasi dengan senyawa silan, menggunakan $\gamma$-Glisidoksil propil trimetoksisilan (GPTMS) dan $\gamma$-Aminopropil trietoksisilan $(\gamma$-APS $) \quad$ serta katalis dibutyltindilaurate (DBTL). Hasil karakterisasi spektroskopi FTIR (Fourier Transform Infra Red) menunjukkan bahwa material pelapis hibrid telah terbentuk. Hasil analisis \% NCO sisa dan konversi isosianat $(\alpha)$ juga memperkuat dugaan material pelapis hibrid ETP - Si telah terbentuk. Penambahan senyawa silan sebagai gugus Si-O sebanyak 30\% menunjukkan \%NCO sisa yang paling rendah untuk material pelapis hibrid dengan konsentrasi poliuretan $5 \%$ dan 10\%. Komposisi ETP 5\% - Si 30\% merupakan komposisi optimum berdasarkan analisis sifat mekanik.
\end{abstract}

Kata Kunci: Pelapis hibrid, poliuretan, epoksi, silan, ETP-Si

\section{ABSTRACT}

Preparation of hybrid coating material from modified epoxy polyurethane (ETP) and silan (Si) has been done. Epoxy and polyurethane were modified with silan using $\gamma$-Glisidoksil propil trimetoksisilan (GPTMS) and $\gamma$-aminopropyl triethoxysilane $(\gamma$-APS) and also dibutyltindilaurate (DBTL) as catalyst. Fourier Transform Infrared (FTIR) characterization indicated that the hybrid coating material has been formed. The results of the analysis of NCO percent and conversion rate of isocyanates $(\alpha)$ also verified that the ETP-Si hybrid coatings have been formed. The addition $30 \%$ of silane as $\mathrm{Si}-\mathrm{O}$ group indicated the rest of $\mathrm{NCO}$ percent was the lowest for hybrid coating material with polyurethane concentration of 5\% and 10. The composition of ETP5\% - Si 30\% was the optimum composition from the ETP-Si hybrid coating material based on the mechanical analysis.

Key words: hybrid coating, polyurethane, epoxy, silane, ETP - Si

\section{PENDAHULUAN}

Teknologi pelapis hibrid (hybrid coating) dewasa ini banyak dimanfaatkan untuk bahan anti korosi. Pelapis atau coating selain tergolong murah, juga mudah untuk dibuat dan diaplikasikan ${ }^{(1)}$. Sistem pelapis berbasis epoksi banyak diaplikasikan di bidang industri transportasi, perkapalan, perminyakan dan alat-alat rumah tangga yang terbuat dari besi.

Sistem pelapis konvensional biasanya menggunakan bahan dari resin organik, yaitu epoksi atau poliuretan. Epoksi tergolong senyawa reaktif, yang memiliki struktur molekul cincin oksirena yang bersifat tidak stabil pada perlakuan panas ${ }^{(2)}$. Kelebihan dari penggunaan resin epoksi sebagai material pelapis adalah sifat mekanik yang tinggi dan ketahanan terhadap korosi, adesi serta lingkungan yang baik ${ }^{(3-5)}$. 
Pembuatan pelapis berbasis poliuretan dan epoksi telah dilakukan oleh Kostrzewa $^{(4)}$ dan dipublikasikan dalam tesis doktoralnya. Epoksi dimodifikasi menggunakan poliuretan yang dibuat dari dua jenis poliol (polietilen glikol dan polioksipropilen diol) dengan dua jenis isosianat juga 2,4-toluene diisosianat (TDI) dan 4,4-difenilmetan diisosianat (MDI) untuk meningkatkan kekuatan pelapis secara mekanik. Hasil penelitian tersebut menunjukkan bahwa modifikasi epoksi dengan poliuretan dari polietilen glikol menyebabkan pelapis menjadi lebih elastis dan fleksibel sedangkan modifikasi epoksi dengan poliuretan dari polioksipropilen diol menyebabkan pelapis menjadi lebih keras. Hal ini menunjukkan bahwa poliuetan dengan poliol yang memiliki bagian lembut yang lebih panjang struktur molekulnya menyebabkan pelapis menjadi lebih kuat dan keras.

Menurut $\operatorname{Keijman}^{(6)}$ sistem pelapis hanya dengan menggunakan resin epoksi memiliki kelemahan yaitu lambat mengering pada suhu rendah, ketahanan terhadap cuaca buruk dan bersifat getas. Berdasarkan penelitian yang merujuk bahwa pelapis dengan hanya menggunakan bahan epoksi memiliki beberapa kelemahan, maka untuk mendapatkan material pelapis yang lebih kuat dan tahan lama perlu dimodifikasi dengan penambahan senyawa polimer lain seperti poliuretan. Senyawa ini memiliki ketahanan terhadap pelarutan dan abrasi serta memiliki sifat tahan terhadap cuaca ${ }^{(7)}$.

Pelapis hibrid (hybrid coating) merupakan sifat dari dua sistem pengikat (binder) yang memiliki sifat yang berbeda yang bekerja sama untuk membentuk satu sistem baru resin. Jenis pelapis ini dihasilkan dari mekanisme persilangan jaringan ikatan untuk meningkatkan stabilitas termal dan karakteristik hidrofobik dibandingkan dengan yang diperoleh dari teknik pencampuran ${ }^{(7)}$.
Ide dasar pengembangan senyawa hybrid coating bahan anorganik-organik adalah kombinasi dari gugus anorganik dan organik pada skala molekul untuk mencapai kombinasi sinergis sifat khas dari masingmasing konstituen. Modifikasi jenis dan proporsi komponen organik dan anorganik memungkinkan disengaja untuk menyesuaikan sifat dan menggabungkan komponen organik dan anorganik ${ }^{(8-12)}$.

Pada penelitian ini telah dilakukan pembuatan pelapis hibrid epoksi termodifikasi poliuretan-senyawa silan (ETP-Si). Harapan dari material pelapis hibrid ETP-Si ini dapat diaplikasikan pada industri transportasi dan perkapalan. Adanya gugus siloksan (ikatan - Si-O-) yang berasal dari senyawa silan diharapkan memberikan sifat material yang memiliki ketahanan terhadap degradasi oleh panas, bahan kimia, dan paparan sinar UV. Ikatan -Si-O- pada siloksan memiliki energi yang lebih besar $(445 \mathrm{Kj} / \mathrm{mol})$ dari pada ikatan $\mathrm{C}-\mathrm{C}-(358 \mathrm{Kj} / \mathrm{mol})^{(13)}$. Dengan adanya modifikasi dari epoksi dengan poliuretan dan senyawa silan, maka material hasil sintesis memiliki sifat mekanik dan ketahanan termal yang lebih baik dibandingkan dengan hanya menggunakan resin epoksi.

Tulisan dari hasil penelitian ini berdasarkan penelitian-penelitian yang sudah dikerjakan sebelumnya ${ }^{(19,20,21)}$, yang sudah memvariasi jenis poliol serta jenis senyawa isosianat (dua komponen tersebut yang membentuk senyawa poliuretan) dan variasi penambahan senyawa polisiloksan (sebagai gugus ikatan $-\mathrm{Si}-\mathrm{O}$ ).

\section{BAHAN DAN METODE}

\section{Bahan}

Bahan yang digunakan dalam penelitian ini terbagi menjadi bahan utama dan bahan untuk analisa. Bahan utama adalah epoksi diglisidil eter bisfenol A (epoksi YD 128 dengan Epoxy Equivalent 
Weight $($ EEW $)=180-190)$, polipropilen glikol (PPG) dengan bilangan hidroksil = 193,262 $\mathrm{mgKOH} / \mathrm{g}$, tolonate HDT (\% NCO $=31,6155 \%$ ), senyawa silan dengan nama dagang Silquest A-187 atau $\gamma$-Glisidoksil propil trimetoksisilan (GPTMS) dan $\gamma$ Aminopropil trietoksisilan ( $\gamma$-APS) serta katalis dibutyltindilaurate (DBTL) yang berfungsi untuk meningkatkan laju reaksi pembentukan senyawa hybrid ETP-Si. Bahan utama epoksi, Silquest A-187, tolonat serta $\gamma$-APS diperoleh dari P.T. Sigma Utama yang bertempat di Cibinong. PPG dan DBTL berasal dari Merck p.a Jerman. Bahan-bahan yang digunakan untuk analisa \% NCO sisa adalah toluen, larutan dibutilamin dalam toluen, 2propanol, larutan $\mathrm{HCl}$ p.a, dan indikator bromtimol biru dalam metanol. Keseluruhan bahan analisa \% NCO yang digunakan berasal dari Merck p.a, Jerman.

\section{Sintesis Epoksi Termodifikasi Poliuretan dan Senyawa Silan (ETP-Si)}

Tabel 1 menunjukkan komposisi berbagai bahan baku yang digunakan dalam pembuatan ETP. Masing-masing komponen seperti epoksi, PPG dan tolonat dimasukkan kedalam labu leher tiga disertai dengan penambahan katalis DBTL. Proses pencampuran dilakukan selama 30 menit pada suhu $70-80 \quad{ }^{\circ} \mathrm{C}^{(9)}$, kemudian ditambahkan silquest A-187 dan $\gamma$-APS. Suhu pencampuran diturunkan menjadi 50 ${ }^{\circ} \mathrm{C}$ dan diaduk selama 1 jam 30 menit. Rasio NCO/OH dalam pembuatan ETP-Si ini adalah 2,5.

\section{Analisa gugus NCO}

Masing-masing formula ETP-Si ditimbang sebanyak $\pm 0,15$ gr dan ditambahkan masing-masing toluena dan dibutil amin sebanyak 12,5 mL. Campuran diaduk selama 15 menit dalam suhu ruang. Sebanyak $50 \mathrm{~mL}$ 2-propanol ditambahkan dalam larutan campuran dan ditetesi 3 tetes indikator bromkresal hijau sampai berwarna biru. Larutan dititrasi dengan larutan $\mathrm{HCl}$ yang sudah distandarisasi. \%NCO sisa dihitung menggunakan Persamaan (1) yang berdasarkan Polymer Testing 28 (2009) ${ }^{(10)}$.

$$
\% N C O=\frac{\left(V_{0}-V_{i}\right) \times N_{H C l} \times 0,042}{W_{\text {sampel }}} \times 100 \%
$$

Keterangan:

$V o$ dan $V i \quad=$ volume $\mathrm{HCl}(\mathrm{mL})$

$\mathrm{N}_{\mathrm{HCl}} \quad$ normalitas $\mathrm{HCl}$

Wsampel = berat sampel (gram)

Tabel 1. Komposisi Material Hibrid ETP-Si

\begin{tabular}{|c|c|c|c|c|c|c|c|}
\hline No & Komposisi & $\begin{array}{l}\text { Epoksi } \\
\text { (gram) }\end{array}$ & $\begin{array}{c}\text { Poliuretan } \\
(\%)^{*}\end{array}$ & $\begin{array}{c}\text { Silane } \\
(\%)^{*}\end{array}$ & $\begin{array}{l}\text { APS } \\
(\%)^{* *}\end{array}$ & $\begin{array}{l}\text { DBTL } \\
(\%)^{* * * *}\end{array}$ & Notasi \\
\hline 1 & ETP5\%-Si10\% & 100 & 5 & 10 & 1 & 0,1 & F1A \\
\hline 2 & ETP5\%-Si20\% & 100 & 5 & 20 & 1 & 0,1 & $\mathrm{~F} 2 \mathrm{~A}$ \\
\hline 3 & ETP5\%-Si30\% & 100 & 5 & 30 & 1 & 0,1 & F3A \\
\hline 4 & ETP5\%-Si40\% & 100 & 5 & 40 & 1 & 0,1 & F4A \\
\hline 5 & ETP10\%-Si10\% & 100 & 10 & 10 & 1 & 0,1 & F1B \\
\hline 6 & ETP10\%-Si20\% & 100 & 10 & 20 & 1 & 0,1 & F2B \\
\hline 7 & ETP $10 \%-S i 30 \%$ & 100 & 10 & 30 & 1 & 0,1 & F3B \\
\hline 8 & ETP10\%-Si40\% & 100 & 10 & 40 & 1 & 0,1 & F4B \\
\hline 9 & ETP20\%-Si10\% & 100 & 20 & 10 & 1 & 0,1 & $\mathrm{~F} 1 \mathrm{C}$ \\
\hline 10 & ETP20\%-Si20\% & 100 & 20 & 20 & 1 & 0,1 & $\mathrm{~F} 2 \mathrm{C}$ \\
\hline 11 & ETP20\%-Si30\% & 100 & 20 & 30 & 1 & 0,1 & $\mathrm{~F} 3 \mathrm{C}$ \\
\hline 12 & ETP20\%-Si40\% & 100 & 20 & 40 & 1 & 0,1 & $\mathrm{~F} 4 \mathrm{C}$ \\
\hline \multicolumn{8}{|c|}{ Keterangan } \\
\hline$*$ & $\%(w / w)$ terhad & $k s i$ & & & & & \\
\hline$* *$ & $\%(w / w)$ terhada & quest & & & & & \\
\hline$* * *$ & $\%(w / w)$ terha & & iretan & & & & \\
\hline
\end{tabular}




\section{Karakterisasi FTIR}

Bahan baku berupa epoksi, PPG, tolonat, silquest A-187 dianalisa menggunakan spektrofotometer Fourier Transform Infra Red (FTIR), IR-Prestige21 SHIMADZU dari Jepang. Selain itu, material hibrid ETP-Si dengan komposisi poliuretan (PU) 5\% dan silquest $10 \%$ dianalisa dengan FTIR untuk mengetahui gugus fungsi struktur kimia masing-masing bahan baku yang digunakan dan produk pelapis yang dihasilkan.

\section{Pengujian Mekanik}

Pengujian mekanik berupa pengujian kuat tarik mengacu pada metode ASTM ${ }^{[11,12]}$. Spesimen uji dengan ukuran $5 \times 70$ $\mathrm{mm}^{2}$ diuji dengan Universal Testing Mechine (UTM) Ray-Ran M500-50CT dengan kecepatan tarik $10 \mathrm{~mm} / \mathrm{menit}$.

\section{HASIL DAN PEMBAHASAN}

\section{Analisis Gugus Fungsi}

Gambar 1 menunjukkan spektra FTIR dari bahan baku dan produk pelapis hibrid. Analisa gugus fungsi dari komponen penyusun pembuatan material pelapis hibrid ETP-Si ini menunjukkan bahwa terdapat pita serapan khas dari struktur senyawa-senyawa tersebut. Spektra FTIR epoksi menunjukkan adanya serapan tajam pada bilangan gelombang 1186,22 $\mathrm{cm}^{-1}$ dimana menunjukkan adanya gugus $\mathrm{C}-\mathrm{O}$ eter serta serapan pada $1190,08 \mathrm{~cm}^{-1}$ yang juga menunjukkan gugus $-\mathrm{C}-\mathrm{O}$ dari cicin epoksi. Spektra FTIR PPG gugus hidroksil ditunjukkan pada bilangan gelombang $3439,08 \mathrm{~cm}^{-1}$.

Analisa FTIR untuk senyawa tolonat menunjukkan adanya serapan di bilangan gelombang $2063,83 \mathrm{~cm}^{-1}$ yang merupakan gugus $-\mathrm{N}=\mathrm{C}=\mathrm{O}$ yang ada pada struktur bahan baku ini, selain itu terdapat pula gugus karbonil pada bilangan gelombang $1764,87 \mathrm{~cm}^{-1}$. Silquest A-187 atau $\gamma$ Glisidoksil propil trimetoksilan mempunyai serapan khas $\mathrm{Si}-\mathrm{O}$ pada bilangan gelombang $906,54 \mathrm{~cm}^{-1}$.

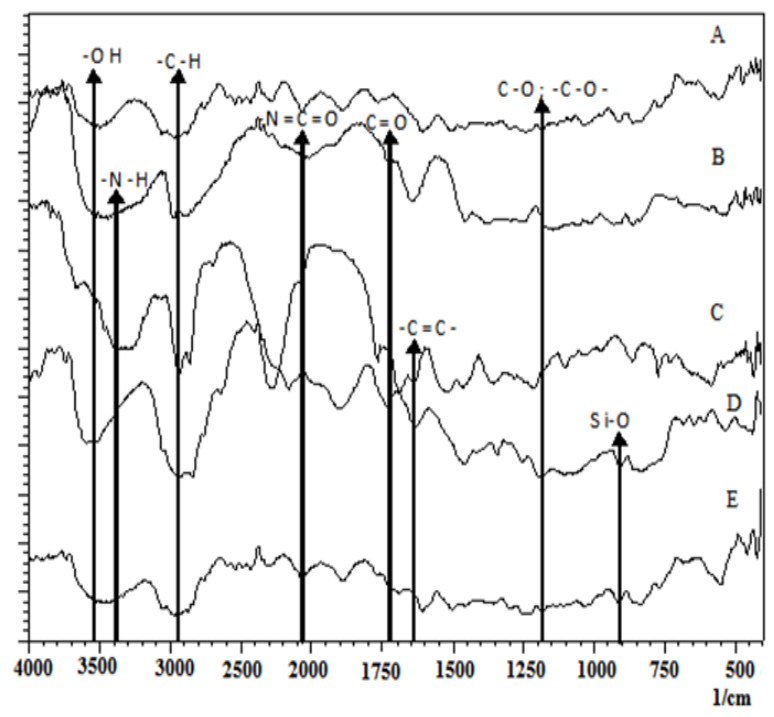

Gambar 1. Spektra FTIR dari (A) Epoksi, (B) Tolonat, (C) PPG, (D) Silquest, (E) Pelapis hibrid epoksi termodifikasisilan (ETP-Si)

Keseluruhan analisa FTIR gugus dari struktur kimia bahan-bahan baku pembentuk pelapis hibrid ini ditunjukkan pada Tabel 2 (berdasarkan Gambar 1).

Spektra FTIR produk pelapis hibrid pada Gambar 1 (E) menunjukkan adanya serapan tajam di $3437,15 \mathrm{~cm}^{-1}$ yang merupakan gugus $-\mathrm{OH}$. Selain itu, terdapat pula serapan khas gugus $-\mathrm{N}=\mathrm{C}=\mathrm{O}$ dari tolonat pada bilangan gelombang 2063,83 $\mathrm{cm}^{-1}$ dan serapan pada rentang 2839,22 sampai $2966,52 \mathrm{~cm}^{-1}$ yang menunjukkan $\mathrm{C}-\mathrm{H}$ streaching dari metil pada $\mathrm{PPG}^{(7)}$.

Kedua serapan ini menunjukkan bahwa ETP telah terbentuk. Terdapat pula serapan di $912,23 \mathrm{~cm}^{-1}$ yang mirip dengan serapan gugus -Si-O yang ada pada senyawa silan. 
Tabel 2. Struktur kimia dan karakteristik spektra FTIR masing-masing komponen penyusun ETP-Si.

\begin{tabular}{|c|c|c|c|}
\hline Senyawa & Struktur kimia & $\begin{array}{c}\text { Bilangan gelombang } \\
\left(\mathrm{cm}^{-1}\right)\end{array}$ & Gugus fungsi \\
\hline $\begin{array}{l}\text { Epoksi diglisidil eter } \\
\text { bisfenol A }\end{array}$ & & $\begin{array}{l}3549,02 \\
2870,08-2962,66 \\
1186,22\end{array}$ & $\begin{array}{l}-\mathrm{OH} \\
-\mathrm{C}-\mathrm{H} \text { str } \\
-\mathrm{C}-\mathrm{O} \text { eter }\end{array}$ \\
\hline tolonat & & $\begin{array}{l}3242,34 \text { dan } 3375,42 \\
2858,51 \text { dan } 2929,87 \\
2063,83 \\
1764,87\end{array}$ & $\begin{array}{l}-\mathrm{N}-\mathrm{H} \\
-\mathrm{C}-\mathrm{H} \text { str } \\
-\mathrm{N}=\mathrm{C}=\mathrm{O} \\
-\mathrm{C}=\mathrm{O}\end{array}$ \\
\hline Poli propilen glikol & & $\begin{array}{l}3439,08 \\
2883,58 \text { dan } 2985,80 \\
1645,28 \text { dan } 1458,18\end{array}$ & $\begin{array}{l}-\mathrm{OH} \\
-\mathrm{C}-\mathrm{H} \text { str } \\
-\mathrm{C}=\mathrm{C}-\end{array}$ \\
\hline Silquest A-187 & & $\begin{array}{l}3547,09 \\
2841,15 \text { dan } 2937,59 \\
1190,08 \\
906,54\end{array}$ & $\begin{array}{l}-\mathrm{OH} \\
-\mathrm{C}-\mathrm{H} \text { str } \\
-\mathrm{C}-\mathrm{O} \text { eter } \\
-\mathrm{Si}-\mathrm{O}\end{array}$ \\
\hline
\end{tabular}
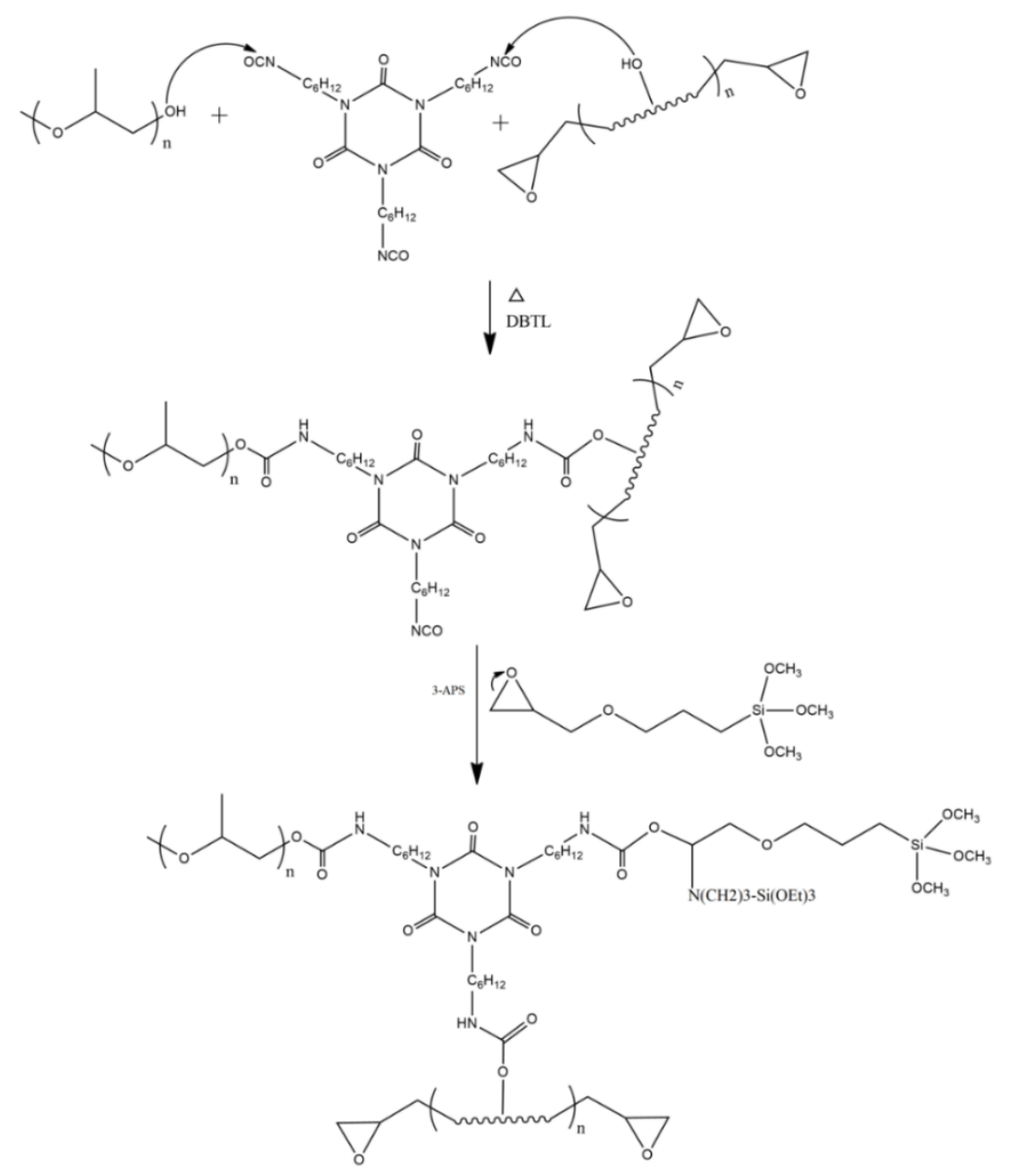

Gambar 2. Prediksi mekanisme reaksi pembentukan senyawa hibrid epoksi termodifikasi-silan (ETP-Si) ${ }^{(7)}$ 
Reaksi polimerisasi pembentukan poliuretan adalah suatu reaksi antara senyawa isosianat dengan suatu poliol ${ }^{(9)}$. Pada penelitian ini isosianat yang digunakan adalah tolonat yang memiliki $\% N C O$ sebesar $31,62 \%$, sedangkan poliol yang digunakan adalah PPG. Adanya gugus hidroksi pada PPG akan berikatan dengan gugus isosianat pada tolonat, dimana ikatan rangkap dari $-\mathrm{C}=\mathrm{N}$ pada tolonat akan terbuka dan menyebabkan atom $\mathrm{C}$ parsial positif. PPG yang memiliki gugus hidroksi akan menyerang atom $\mathrm{C}$ parsial positif dan membentuk ikatan uretan $(-\mathrm{N}(\mathrm{C}=\mathrm{O}) \mathrm{O}-)$ sesuai dengan mekanisme reaksi pada Gambar 2.

\section{Analisis \% NCO Sisa}

Grafik hubungan antara \% silquest dalam ETP-Si dengan \% sisa NCO dari masing-masing formulasi ditunjukkan pada Gambar 4. Dari data tersebut terlihat bahwa, semakin banyak kadar dari silquest menyebabkan \% sisa dari NCO semakin berkurang. Hal ini terjadi karena adanya gugus hidroksi dari silquest yang berasal dari gugus oksirena (epoksi) yang semakin banyak, maka menyebabkan semakin banyak pula ikatan uretan yang terbentuk. Sehingga, gugus isosianat dari tolonat terkonversi menjadi ikatan uretan.

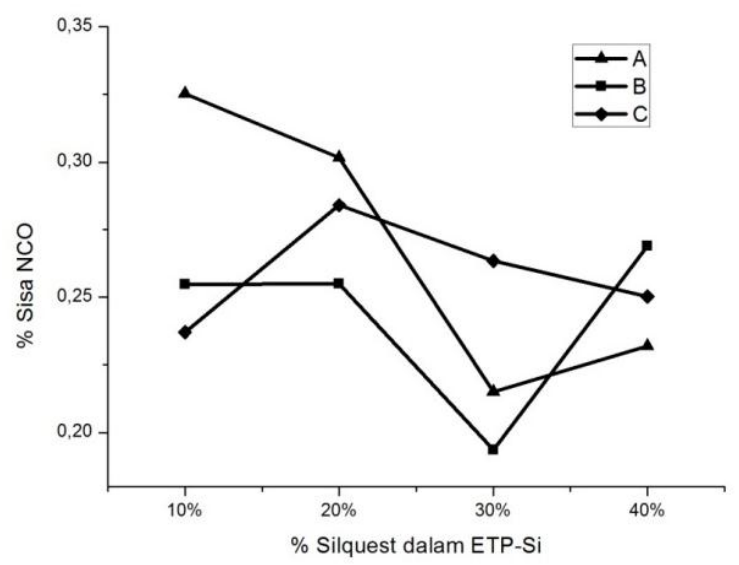

Gambar 3. Grafik \% sisa NCO dalam (A) ETP5\%, (B) ETP10\% dan (C) ETP20\%
Prinsip dari analisa NCO ini adalah titrasi asam-basa, yang bertujuan untuk mengetahui masih ada atau tidaknya gugus isosianat yang ada pada material pelapis hibrid ETP-Si yang dilarutkan dalam campuran toluena dan dibutil amin dan dititrasi dengan $\mathrm{HCl}$. Dibutil amin yang bersifat basa dan $\mathrm{HCl}$ sebagai asam akan berekasi membentuk garamnya. Jika di dalam sampel ETP-Si terdapat gugus NCO, maka dibutil amin akan bereaksi dengan gugus NCO sehingga membentuk suatu garam atau produk. Produk ini jika dititrasi dengan asam klorida tidak akan membentuk garam butan-1-amina dan 1-klorobutana yang memberikan perubahan warna pada sampel, semakin banyak sisa NCO maka asam klorida yang dibutuhkan untuk titrasi akan semakin sedikit. Adapun mekanisme reaksinya ditunjukkan oleh Gambar 4.

Dari perhitungan \% sisa NCO maka diperoleh tingkat konversi isosianat yang ditunjukkan oleh Tabel 3. Tingkat atau derajat konversi isosianat adalah persentase dari gugus isosianat yang bereaksi membentuk ikatan uretan dengan bahan baku lainnya. Jika derajat konversi isosianat mendekati atau sama dengan $100 \%$, maka gugus isosianat yang ada di dalam sistem telah bereaksi. Tabel 3 menunjukkan bahwa bila dilihat dari konversi isosianat yang nilainya hampir sama yaitu sekitar $99 \%$, sehingga hal ini menunjukkan bahwa pada berbagai variasi tersebut reaksi telah berjalan dengan sempurna.

\section{Sifat Mekanik ETP-Si}

Analisa sifat mekanik dengan menggunakan metode ASTM D 638-10 bertujuan untuk mengetahui karakterkarakter secara mekanik dari berbagai komposisi material pelapis hibrid ETP-Si. Selain itu, dari hasil analisa ini dapat ditentukan komposisi optimum dari material pelapis hibrid ETP-Si berdasarkan kekuatan mekaniknya. 


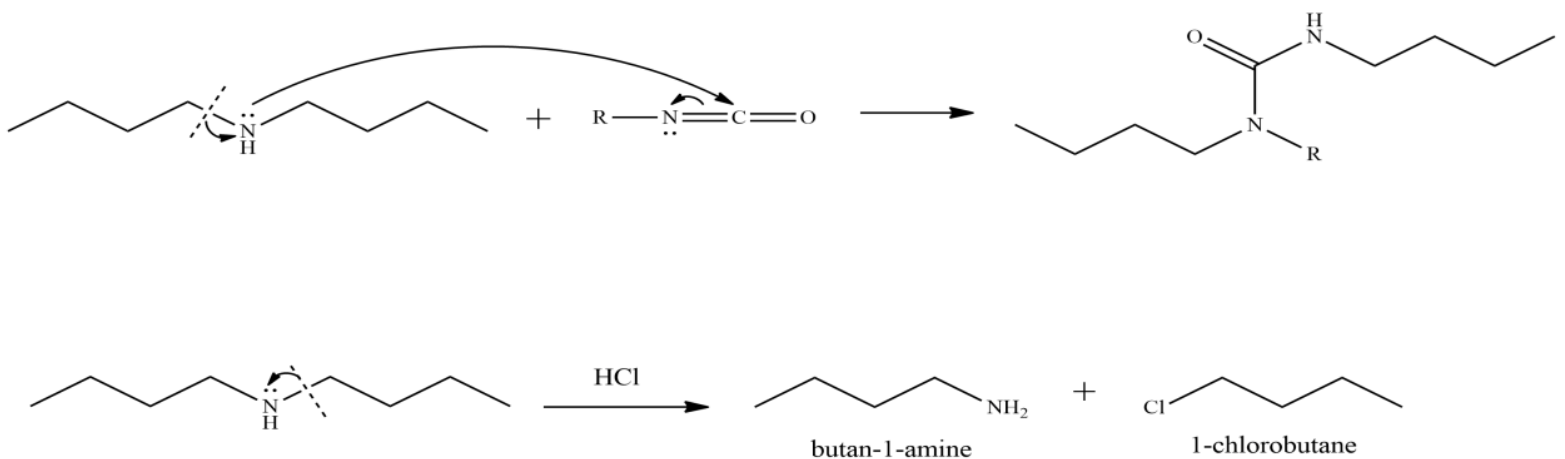

Gambar 4. Kemungkinan mekanisme reaksi titrasi penentuan \% NCO sisa

Tabel 3. Tingkat konversi isosianat dalam ETP-Si

\begin{tabular}{clcc}
\hline No & Komposisi & NCO sisa (\%) & $\boldsymbol{\alpha}(\mathbf{\%})$ \\
\hline 1 & ETP5\%-Si10\% & 0.33 & 98.97 \\
2 & ETP5\%-Si20\% & 0.30 & 99.04 \\
3 & ETP5\%-Si30\% & 0.22 & 99.32 \\
4 & ETP5\%-Si40\% & 0.23 & 99.27 \\
5 & ETP10\%-Si10\% & 0.25 & 99.19 \\
6 & ETP10\%-Si20\% & 0.26 & 99.17 \\
7 & ETP10\%-Si30\% & 0.19 & 99.39 \\
8 & ETP10\%-Si40\% & 0.27 & 99.15 \\
9 & ETP20\%-Si10\% & 0.24 & 99.25 \\
10 & ETP20\%-Si20\% & 0.28 & 99.10 \\
11 & ETP20\%-Si30\% & 0.26 & 99.17 \\
12 & ETP20\%-Si40\% & 0.25 & 99.21 \\
\hline
\end{tabular}

Adapun sifat mekanik yang dianalisa dengan menggunakan alat Universal Testing Mechine (UTM) Ray-Ran tipe M500-50CT ini adalah kekuatan tarik (tensile strenght), \% elongasi dan modulus young pada Tabel 4.

\section{Tensile strength (kuat tarik)}

Kuat tarik atau tensile strenght merupakan salah satu karakter dari pengujian mekanik

Kuat tarik menunjukkan kuat atau tidaknya suatu material saat diberikan gaya tarik secara vertikal. Tabel 4 menunjukkan kekuatan tarik dari berbagai komposisi ETP-Si. Dari data kuat tarik didapat bahwa formula ETP-Si F1B dengan komposisi ETP10 \%-Si10 \% memiliki kekuatan tarik lebih besar, yaitu $55.13 \pm 2.61 \mathrm{MPa}$. Jika ditelaah lebih lanjut, ternyata pada penambahan silan $10 \%$ untuk masing- masing komposisi ETP-Si baik ETP $5 \%$, $10 \%$ dan $20 \%$ memiliki kekuatan tarik yang lebih besar dibandingkan sampel dengan komposisi silan 10, 20 dan $40 \%$.

Gambar 5 menunjukkan grafik dari pengaruh penambahan poliuretan terhadap sifat kuat tarik ETP pada konsentrasi silan 10\%. Dari data tersebut diperoleh bahwa penambahan poliuretan $10 \%$ memberikan sifat kuat tarik yang lebih besar dibandingkan penambahan $5 \%$ maupun 20 $\%$. Selain itu, adanya penambahan poliuretan $10 \%$ mampu meningkatkan sifat kuat tarik dari epoksi.

Penambahan senyawa silan pada material ETP-Si juga mempengaruhi sifat mekanik dari material tersebut. Gambar 6 menunjukkan pengaruh penambahan senyawa silan pada material ETP-Si dengan konsentrasi poliuretan $10 \%$. Adanya penambahan senyawa silan yang semakin banyak ternyata menurunkan sifat kuat tarik dari material ETP-Si. Sedangkan menurut Lul et $a l^{(3)}$ kehadiran epoksi sebagai bahan baku akan memberikan sifat mekanik yang lebih baik. Adanya penurunan kuat tarik pada penambahan senyawa silan pada konsentrasi 20 sampai $40 \%$ tidak terikat dalam struktur dari ETP. Penambahan $10 \%$ senyawa silan merupakan komposisi yang optimum dari pembuatan ETP-Si, sehingga jika dilakukan penambahan senyawa silan berlebih maka kemungkinan tidak bereaksi dengan ETP dan mengakibatkan turunnya sifat mekanik dari ETP-Si. 
JKTI, Vol. 17, No. 1, Juni 2015 : 15 - 26

Tabel 4. Sifat mekanik material pelapis hibrid ETP-Si

\begin{tabular}{lccc}
\hline \multicolumn{1}{c}{ Komposisi } & Kuat Tarik (MPa) & Elongasi (\%) & Modulus Young (GPa) \\
\hline Epoksi & $44.65 \pm 8.13$ & $1.35 \pm 0.49$ & $340.81 \pm 62.70$ \\
ETP5\%-Si10\% & $41.71 \pm 1.08$ & $1.98 \pm 0.32$ & $213.09 \pm 29.41$ \\
ETP5\%-Si20\% & $36.13 \pm 2.38$ & $2.58 \pm 0.43$ & $140.98 \pm 13.99$ \\
ETP5\%-Si30\% & $32.52 \pm 0.68$ & $2.44 \pm 0.26$ & $133.58 \pm 11.24$ \\
ETP5\%-Si40\% & $25.73 \pm 1.27$ & $1.25 \pm 0.02$ & $205.67 \pm 6.49$ \\
ETP10\%-Si10\% & $55.13 \pm 2.61$ & $2.19 \pm 0.09$ & $251.13 \pm 4.73$ \\
ETP10\%-Si20\% & $38.41 \pm 0.38$ & $1.19 \pm 0.29$ & $330.67 \pm 77.34$ \\
ETP10\%-Si30\% & $29.24 \pm 0.85$ & $2.05 \pm 0.32$ & $144.78 \pm 18.78$ \\
ETP10\%-Si40\% & $33.55 \pm 0.93$ & $1.54 \pm 0.51$ & $236.74 \pm 86.01$ \\
ETP20\%-Si10\% & $38.78 \pm 2.07$ & $2.35 \pm 1.29$ & $196.39 \pm 116.18$ \\
ETP20\%-Si20\% & $32.84 \pm 2.48$ & $2.43 \pm 0.48$ & $137.41 \pm 22.01$ \\
ETP20\%-Si30\% & $21.37 \pm 0.38$ & $1.09 \pm 0.24$ & $199.35 \pm 40.08$ \\
ETP20\%-Si40\% & $28.43 \pm 0.04$ & $1.94 \pm 0.29$ & $149.41 \pm 22.71$ \\
\hline
\end{tabular}

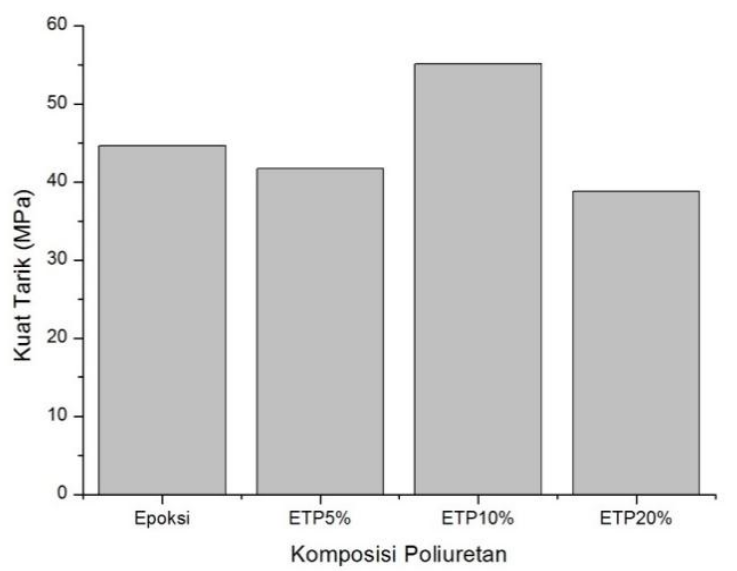

Gambar 5. Kekuatan tarik berbagai komposisi ETP pada silan $10 \%$

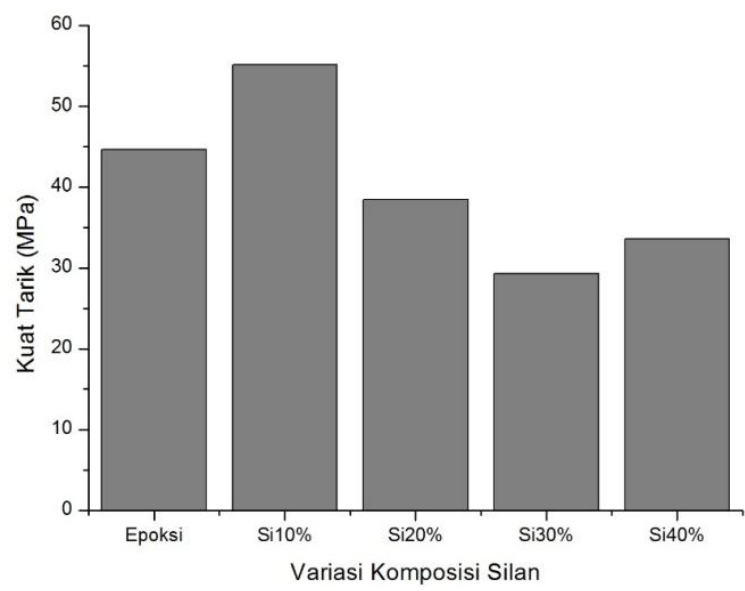

Gambar 6. \% Pengaruh variasi senyawa silan pada kuat tarik dengan konsentrasi poliuretan $10 \%$.

\section{Persen (\%) elongasi}

Analisa \% elongasi adalah suatu persentase pertambahan panjang suatu spesimen uji saat dilakukan penarikan secara vertikal. \% elongasi menunjukkan keelastisan suatu material yang ditunjukkan dengan adanya kemuluran pada spesimen uji saat diberikan gaya tertentu. Gambar 7 menunjukkan \% elongasi penambahan berbagai komposisi poliuretan pada material pelapis hibrid ETP-Si10 \%. Pada sampel dengan silan $10 \%$, ternyata $\%$ elongasi dari material pelapis hibrid ETP-Si meningkat dengan penambahan konsentrasi dari poliuretan. Hal ini terjadi karena poliuretan adalah suatu material termoplastik yang memiliki sifat elastis. Pada penelitian yang dilakukan oleh Barletta et $a l^{(17)}$, poliuretan memiliki \% elongasi sebesar $57.86 \%$, sedangkan epoksi sebesar $18.87 \%$. Sehingga dengan adanya penambahan poliuretan, maka \% elongasi dari material pelapis hibrid ETP-Si semakin besar. 


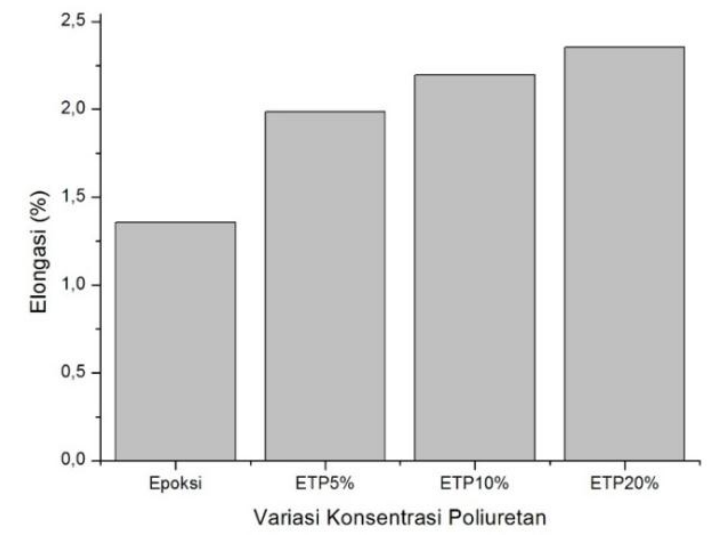

Gambar 7. Persen elongasi berbagai komposisi ETP pada Si $10 \%$

Adapun pengaruh penambahan senyawa silan dalam elastisitas material pelapis hibrid ETP-Si ditunjukkan pada Gambar 8. Dari gambar tersebut diperoleh bahwa penambahan senyawa silan ternyata mempengaruhi persen elongasi dari material ETP Si secara fluktuatif. Senyawa silan yang digunakan pada penelitian ini memiliki gugus oksirena dimana bersifat kaku seperti epoksi. Oleh karenanya, dengan adanya penambahan senyawa silan, akan menyebabkan material pelapis hibrid ETP-Si menjadi kaku atau kurang elastis. Hal ini menyebabkan elongasi dari material ini berkurang dengan penambahan senyawa silan.

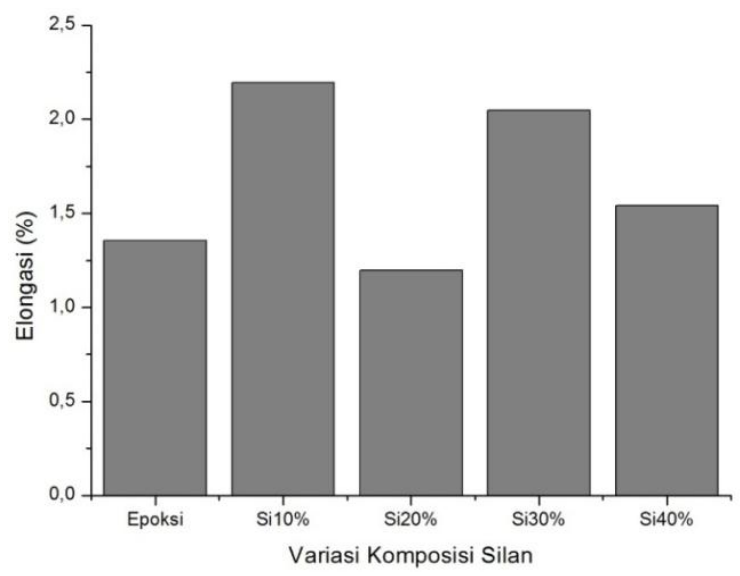

Gambar 8. Persen elongasi material ETP $10 \%$ dengan variasi senyawa silan

\section{Modulus young}

Selain data kekuatan tarik dan elongasi, dari pengujian mekanik ini juga diperoleh data modulus young. Modulus young didefinisikan sebagai rasio tegangan dalam sistem koordinasi kartesian terhadap regangan sepanjang aksi pada jangkauan tegangan dimana hukum hook berlaku ${ }^{[18]}$.

Jika suatu bahan semakin kaku, maka harga dari modulus young akan semakin besar, karena pada material yang memiliki tingkat kekakuan yang besar memerlukan energi yang besar pula untuk menarik material tersebut sampai putus, tetapi pertambahan panjang atau sifat elastisitas dari material tersebut rendah. Data modulus young yang ditunjukkan oleh Gambar 9 memberikan profil tentang korelasi kekuatan tarik dengan elongasi (ukuran elastisitas suatu material) untuk material pelapis hibrid ETP-Si $10 \%$ dengan berbagai variasi konsentrasi poliuretan.

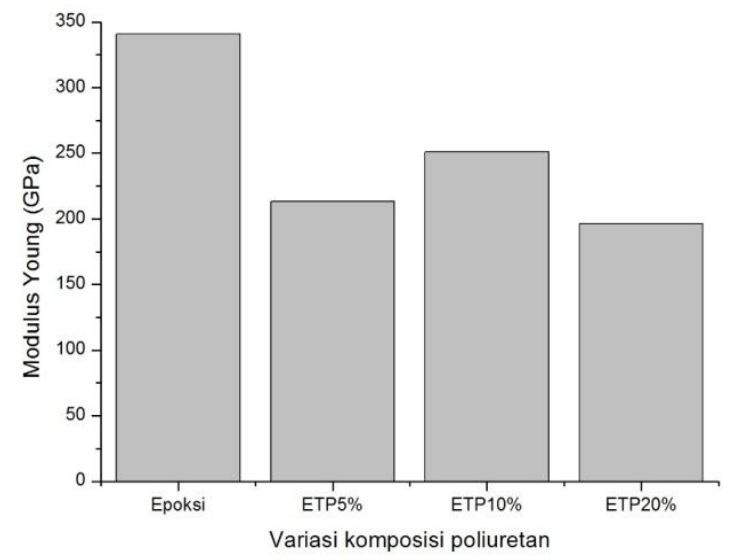

Gambar 9. Modulus Young material ETP-Si $10 \%$ dengan variasi poliuretan

Gambar 9 menunjukkan penambahan poliuretan yang memiliki sifat elastisitas menurunkan harga modulus young dari suatu material. Hal ini selaras dengan dengan definisi modulus young tersebut, yang berbanding lurus dengan kuat tarik dan berbanding terbalik dengan elastisitas. Apabila suatu material memiliki sifat elastisitas yang tinggi, maka modulus young 
akan rendah. Modulus young juga dapat menerangkan kekakuan dari suatu material.

Pada material epoksi tanpa penambahan poliuretan memiliki harga modulus young sebesar $340.81 \pm 62.70$ GPa. Hal ini terjadi karena sifat kekakuan dari material ini tinggi sedangkan elastisitasnya yang rendah, karena itu harga modulus young dari epoksi akan tinggi.

Berbeda jika pada material epoksi yang ditambah dengan poliuretan (ETP), penambahan poliuretan akan meningkatkan sifat elastisitas dari suatu material yang menyebabkan faktor kekakuannya akan menurun. Pada komposisi poliuretan 10\% memiliki harga modulus young yang lebih tinggi dibandingkan komposisi. Hal ini terjadi karena komposisi ini memiliki kuat tarik dan elastisitas yang lebih tinggi dibandingkan dengan komposisi-komposisi yang lain. Pengaruh penambahan senyawa silan juga mempengaruhi nilai modulus young dari material ETP-Si yang ditunjukkan oleh Gambar 10.

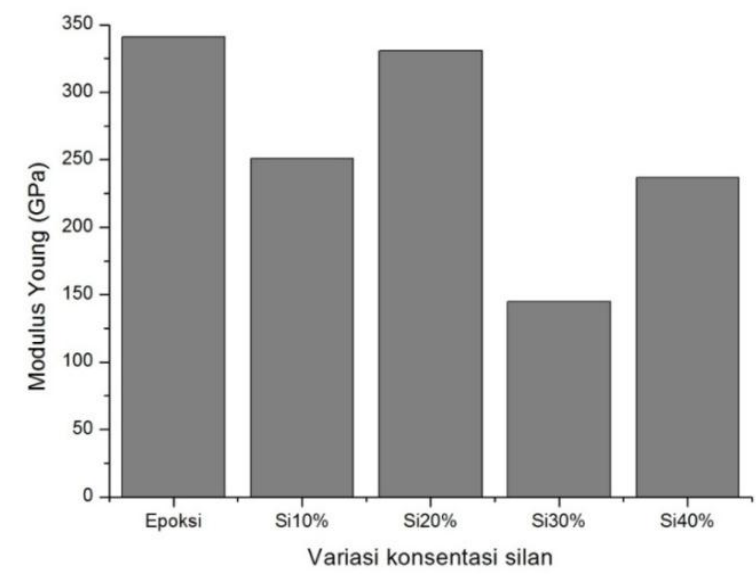

Gambar 10. Pengaruh konsentrasi silan terhadap modulus young ETP-Si

Seperti yang dijelaskan sebelumnya bahwa senyawa silan yang digunakan pada penelitian ini memiliki gugus oksirena yang memiliki karakter mekanik yang sama dengan epoksi. Penambahan senyawa silan dengan konsentrasi $20 \%$ memberikan harga modulus young yang hampir mirip dengan epoksi yaitu $330.67 \pm 77.34 \mathrm{GPa}$.

Jika dilihat dari data kuat tarik dan \% elongasi (Gambar 5, 6, 7 dan 8) komposisi ini memiliki karakter yang hampir mirip dengan epoksi. Oleh karenanya dapat disimpulkan bahwa pada komposisi ini pengaruh dari poliuretan maupun senyawa silan terhadap sifat mekanik dari epoksi kecil.

Nilai persen elongasi dan modulus young trendnya tidak beraturan, hal ini disebabkan karena reaksi pembuatan ETPSi dilakukan secara simultan, jadi struktur jaringan ikat silang polimer yang terbentuk tidak beraturan dimana akan mempengaruhi sifat mekanik sesuai dengan data-data pada Tabel 4.

\section{KESIMPULAN}

Karakterisasi gugus fungsi dengan menggunakan spektrofotometri FTIR menunjukkan bahwa material pelapis hibrid ETP-Si telah terbentuk yang dilihat dari adanya pergeseran dan hilangnya spektra beberapa raw material yang ada pada spektra FTIR ETP-Si. Hal ini didukung juga dengan data analisa \% NCO sisa dan tingkat konversi isosianat yang menunjukkan hampir semua isosianat bereaksi dengan bahan baku lainnya.

Pengujian mekanik menunjukkan bahwa penambahan konsentrasi poliuretan yang semakin banyak mampu meningkatkan sifat elastisitas dari material ETP-Si pada komposisi silan $10 \%$. Dari hasil pengujian mekanik diperoleh bahwa material dengan formulasi ETP $10 \%$-Si 10 $\%$ memiliki kekuatan mekanik yang lebih besar dibandingkan dengan formulasi ETP$\mathrm{Si}$ lainnya. Jika dibandingkan dengan penelitian sebelumnya [21], dengan menggunakan senyawa polisiloksan sebagai ikatan - Si - O, kuat tarik yang dihasilkan lebih besar (10.8 $\mathrm{MPa})$ dan \% elongasi lebih kecil (2.92). 


\section{UCAPAN TERIMAKASIH}

Penulis mengucapkan terima kasih kepada Program Kompetitif LIPI 2014 atas dukungan finansial yang telah diberikan. Penulis juga mengucapkan terima kasih kepada Ibu Hadidjah dan saudara Herlan Herdiawan yang telah membantu dalam pelaksanaan penelitian

\section{DAFTAR PUSTAKA}

1. S.Ahmad, F.Zafar, E. Sharmin, N. Garg, M. Kashif. Progress in Organic Coatings. Vol. 73: 112- 117 (2012).

2. T. M. Goulding. Epoxy Resin Adhesives. CRC Press. Chapter 43 (2003).

3. S. Lul, J. Ban, C. Yu, and W. Deng. Iranian Polymer Journal. Vol. 19 (9): 669-678 (2010).

4. M., Kostrzewa. Thesis. Thomas Bata University in Zlin. 2011.

5. C. A., May. Epoxy Resin Chemistry and Technology, 2nd Edition. Marcel Dekker: New York. 1988.

6. J.M. Keijman. Properties and use of inorganic polysiloxane hybrid coatings for the protective coatings industry. $2^{\text {as }}$ Jornadas Da Revista Corrosão E Protecção de Materiais. Lisboa. 2000.

7. A., Prabu dan M., Alagar. Mechanical and Thermal Studies of intercrosslinked networks based on siliconized polyurethane-epoxy/unsaturated polyester coatings. Progress in Organic Coatings, 49, 236-243. (2004).

8. D.K., Chattopadhay and K.V.S.N., Raju. Structural engineering of polyurethane coatings for high performance applications. Prog. Polym. Sci. 32, 352 - 418 (2007).

9. F. M. B., Countinho. M. C., Delpech. and L. S. Alves. Journal of Applied
Polymer Science. vol. 80: 566-572. (2001).

10. Polymer Testing 28. pp. 773 - 779 . 2009.

11. ASTM D 638-14. Standard Test Method for Tensile Properties of Plastic.

12. ASTM D 882-12. Standard Test Method for Tensile Properties of Thin Plastic Sheeting.

13. K. B. Gireesh, K. K. Jena, S. Allaudin, K. R. Radhika, R. Narayan, K. V. S. N. Raju. Progres in Organic Coating. Vol. 68: 165-172 (2010).

14. T. J. Lee, S. H. Kwon, B. K. Kim. Progress in Organic Coating. Vol. 77: 1111-1116 (2014).

15. C. Fu, Z. Yang, Z. Zheng, L. Shen. Progress in Organic Coating. Vol. 77: 1241-1248 (2014).

16. I. Diaz, B. de la Fuente Chico, D. Simancas, J. Vega, J. M. M. Morcillo. Progress in Organic Coating. Vol. 69: 278-286 (2010).

17. M. Barletta, S. Pezzola, M. Puopolo, V. Tagliaferri, S. Vesco. Material and Design. Vol. 54: 924-933 (2014)

18. A. D. McNaught, and A. Wilkinson. IUPAC: Compendium of Chemical Terminology, 2nd ed. (the "Gold Book"). Blackwell Scientific Publications: Oxford. 1997.

19. E. Triwulandari, M. Ghozali, A. Haryono. Karakteristik binder epoksi sebagai bahan coating dengan variasi jenis dan komposisi hardener. Seminar Nasional Kimia Terapan Indonesia. Solo. ISSN 2088-9828. 2013

20. Savitri, M. Ghozali, E. Triwulandari. Karakteristik Binder Epoksi Termodifikasi Poliuretan (ETP) Sebagai Bahan Coating Dengan Variasi Jenis Dan Komposisi Poliol. Prosiding Seminar Nasional Ilmu Pengetahuan 
JKTI, Vol. 17, No. 1, Juni $2015: 15$ - 26

Teknik. Yogyakarta. ISSN 2303-0798. 2013.

21. E. Triwulandari, A. Haryono, M. Ghozali, Savitri, Y. A. Devi, Hadidjah. Proses pembuatan hybrid coating berbasis epoksi termodifikasi poliuretan dan polisiloksan sebagai bahan anti korosi pada logam. Draft paten dengan nomor pendaftaran P05122013. Tangerang. 2013. 